\title{
THE IMPORTANCE OF INTRODUCING A MERIT-BASED HIRING SYSTEM IN NORTH MACEDONIAN GOVERNMENTS
}

\author{
Larry Hubbell \\ Seattle University \\ hubbell1@ seattleu.edu \\ Veli Kreci \\ Research Institute Max van der Stoel, South East European University \\ v.kreci@seeu.edu.mk
}

\begin{abstract}
In this article, the authors present several topics related to the nascent development of a meritbased hiring system in North Macedonia. This paper employs a normative approach. We advocate for a merit-based hiring system, similar to the American model. First, we explore the pressure exerted by the European Commission to adopt a merit-based system at all levels of government as a condition for entry into the European Union. Second, we delve into the patronage system in North Macedonia. Third, we provide a short history of patronage in the United States and the difficulty that nation had in curbing its entrenched patronage system. Fourth, we discuss the advantages of a merit-based hiring system, namely the creation of good governance, the improvement of employee morale, the development of more public confidence in government, the reduction of the influence of ethnic politics and the furtherance of the rule of law. Finally, we present an example drawn from the American federal government about the basic procedures of a merit-based hiring process.
\end{abstract}

Key words: merit-based hiring system, patronage, North Macedonia, ethnic divisions.

\section{INTRODUCTION}

In 2018, the Republic of North Macedonia made some great strides in its greater integration into Euro-Atlantic structures by resolving its long-standing name dispute with Greece. The country, which was previously known as the Former Yugoslav Republic of Macedonia 
(FYROM) ${ }^{1}$, in 2019 officially became the Republic of North Macedonia as a result of a twothirds affirmative vote in both country's parliaments confirming the Prespa Agreement, which concluded the name dispute ${ }^{2}$. This more than 25-year dispute between FYROM and Greece had prevented FYROM from joining both the Council of Europe and its economic counterpart the European Union and NATO. At the time of writing this article, North Macedonia will start accession negotiations to fulfill the obligations of EU membership. Most observers expect that negotiation to result in a successful conclusion and that it will take a great deal of negotiations until the accession is completed.

Nevertheless, although most observers believe that the most significant sticking point that prevents North Macedonia from joining the European Union is its name, other conditions for membership still exist. A key criterion for accession as defined at the European Council in Copenhagen 1993 has come to be known as the "Copenhagen criteria," which requires future member countries meet broader goals of 'respecting democratic values of the EU and a commitment to promoting them'. Explicitly those goals include the following:

- Stable institutions guaranteeing democracy, the rule of law, human rights and respect for protection of minorities;

- A functioning market economy and the capacity to cope with competition of market forces in the EU;

- The ability to take on and implement effectively the obligations of membership, including adherence to the aims of political, economic and monetary union (Commission to the European Parliament, 2018)

Beyond these broad goals, the European Commission, targeting the Western Balkans in particular, also laid out the following specific objectives that countries seeking membership need to achieve. Namely, establishing democratic and professional public administration which falls within the scope of our paper, the Commission noted the following:

- Public administration reform is paramount to strengthening governance at all levels. This includes improving the quality and accountability of administration, increasing

\footnotetext{
${ }^{1}$ As defined under the UN Security Council Resolution 817-1993. The link to the Resolution https://documents-dds-ny.un.org/doc/UNDOC/GEN/N93/203/74/IMG/N9320374.pdf?OpenElement ${ }^{2} \mathrm{http} / / / \mathrm{mfa} . g o v . m k / i n d e x . p h p ? o p t i o n=c o m \_c o n t e n t \& v i e w=a r t i c l e \& i d=2976: q-a-o n-p r e s p a-$ agreement $\&$ catid $=52 \&$ Itemid $=684 \&$ lang $=\overline{\mathrm{mk}}$
} 
professionalism, de-politicisation and transparency, also in recruitment and dismissals, more transparent management of public finances and better services for citizens.

Referring specifically to FYROM, the European Commission noted that:

The country is moderately prepared with the reform efforts of its public administration. Good progress has been made with the adoption of the public administration reform strategy and the public financial management reform programme (ibid, p. 10).

Nevertheless, they added this caveat:

Strong political commitment to guarantee the professionalism of the public administration, especially senior management appointments with respect for the principles of transparency, merit and equitable representation in line with the spirit and the letter of the law remains essential (ibid, p. 10).

It is with these thoughts in mind that we write this article.

\section{PATRONAGE AS A DEFINING VALUE SYSTEM}

What is most notable about North Macedonia's political parties are not their ideologies, but instead their ethnic identities. Although such a statement falls short in labeling political parties as ethnic parties, according to Taleski all political parties in the country have played with ethnonationalism, using it as a tool to attract voters (2008, p.139). Further, Shala through sequencing analysis of voter behavior "shows that the primary voter mobilization is based on ethnic identity of the voter"3. Many authors have struggled to make a distinction between whether a political party can be considered an ethnic party and how much ethnic identity influences the formation of the party itself. Whereas authors such as Skaric puts ethnic identity as a key factor in the formation of political parties in [Macedonia] (2004, 309-335), Mojanoski, differentiates between "parties of the Macedonian nation and the parties of nationalities" (1996). One has to recognize the importance of ethnic identity in the political party system however, political parties tend to shift their focus to ideological differences once the ethnic identity of a political party is established. According to Berat, "In the Republic of Macedonia, there are no multi- 
ethnic parties, but we have quite ethnic parties and their number pretty high compared to the ethnic population" (2017, p. 115).

How political parties are formed greatly influences public administration systems in cases where there are not well-established principles of efficient public administration. This is more than evident in transition countries that are going through reforms to reestablish the functionality of their systems. In the process of reform, political parties take great advantage of the mobilization of their constituents. These political parties have primarily served as avenues to reward their political supporters with government largesse both in the form of government services and government jobs. As Crowther notes, "Civil servants [in Macedonia] are responsible in the first instance to their party, which undermine both efficient administration and accountability" (2017, p. 754). Previously in FYROM, like all governmental systems in which patronage is dominant, distributed government resources inequitably among its citizens. Indeed, the patronage system was rife in FYROM and is also pervasive currently in North Macedonia.

The key to any political patronage system is rewarding your supporters and thus loyalty to the political party takes precedence over any other value. The formula is relatively simple: the political party provides services and jobs to its supporters and, in turn, its supporters help elect their sponsoring political party. Such a pattern has also been true during much of the history of the United States and is also present in many governments throughout the world.

Currently, patronage systems are deeply entrenched in modern day North Macedonia. Although reforms laid out in the so-called "Urgent Reform Priorities," if fully implemented will transform government service-free from party influence, restoring the accountability, and providing quality of services. However, prior to the 2017 Parliamentary elections, the European Commission expressed some serious reservations about the reforms undertaken.

The implementation of the new merit recruitment and appraisal procedures enshrined in the 2015 law on administrative servants began in September 2016. However, rather than being suspended, temporary contracts continued to be transformed into permanent ones without open competition. This was contrary to the 'Urgent Reform Priorities', as it ran counter to the basic principle of merit in public administration and bypassed the new uniform rules for public sector employees. No figures were made public on the number and type of such contracts. Concerns remained also over the transparency of staff mobility and possible misuse of dismissal 
procedures. Criteria for senior management positions should be made more detailed to limit political appointments and dismissals (European Commission, 2016).

Clearly, the new government led by the Social Democratic Union of Macedonia (SDSM) needs to adhere to the reform agenda and root out corruption in government.

Of course, corruption is not unique to government in North Macedonia. It is pervasive throughout North Macedonian society. According to the "Corruption Perceptions Index, 2018" which draws upon 13 surveys and experts and is compiled by Transparency International, FYROM was judged to be one of the most corrupt countries in Europe and overall ranked 93 among 180 countries (a ranking of 1 was the least corrupt country). This is extremely troubling since a strong penchant for corruption undermines the rule of law and is an indication that what matters in such a society is who one knows and/or is associated with.

\section{THE AMERICAN EXPERIENCE WITH PATRONAGE}

Patronage is a phenomenon that is pervasive in governments throughout the world. It was especially prevalent in the United States during much of its history. We delve into the American experience with patronage because we believe that it is instructive regarding how a patronage system develops and also more importantly how it can be rooted out. There obviously are differences and similarities between the American experience with patronage and the Macedonian experience. As to a difference, the United States is not divided by ethnic differences to the extent that occurs in North Macedonia, providing a particularly fertile ground for patronage. A similarity is that in both countries the patronage system provided their citizens with an important source of employment. Furthermore, what may be interesting to North Macedonians is the difficulty that the United States had in largely ridding itself of its patronage systems. A patronage system is very difficult to dislodge. In the American case, it took more than 150 years.

Beginning with the presidential administration of Andrew Jackson in 1833, the United States federal government began implementing a patronage system. Indeed, Jackson is considered by scholars to be the "father" of the patronage system in the federal government. (In turn, this model was emulated by most state and local governments.) By using patronage, Jackson filled most of the positions in his government with loyal members of the Democratic Party. Subsequent Republican Party presidential administrations also rewarded their party stalwarts. 
However, the patronage system was not without some detractors. The first organized opposition to the patronage system came from the Progressive Movement, which was a movement of largely middle and upper middle-class citizens who favored "good government" and civil service reform. (Nevertheless, although the Progressive Movement served to increase government employee's competence, it also provided significant benefits to the very classes who supported these civil service reforms in the form of more jobs for educated middle class and upper middle-class individuals.)

The Progressives favored practical examinations as the means of hiring qualified applicants for government positions. It was their goal that government workers demonstrate what they called "neutral competence." Furthermore, the people selected through this process would keep their positions when an administration changed whether it was at the federal, state or local level. Of course, no system is without its defects and even to this day, on occasion, candidates receive career appointments because of their political connections. As one scholar noted, "while no bureaucracy was ever totally neutral, the premise of nonpoliticization was generally believed to be beneficial, if not indispensable for a society" (Suleiman, 2003, p. 18).

The Progressive Movement was a force behind the passage of the Pendleton Act in 1883, which made roughly ten percent of federal employees subject to the merit system. This movement was also a critical factor behind establishing the council manager form of government in cities and towns throughout the United States. (In the council manager form of government, municipalities are managed by a career official, who is, in turn, appointed by a town's mayor or city council. That city manager appoints senior career officials, who, in turn, appoint junior officials through a merit-based system.)

At the beginning of his administration in the early 1930s, President Franklin Roosevelt engaged in what is called "ideological patronage" within the federal government. In a system of ideological patronage, one's ideology takes precedence over one's party's affiliation. Ideological patronage was important to Roosevelt at this time, because he was initiating programs that his Republican predecessors had avoided. Many of these programs were controversial at the time, because they redistributed income and created new government regulations. These were initiatives, especially favored by the left-wing of the Democratic Party. However, eventually Roosevelt moved away from patronage, in part, because of the recommendation of an expert panel he created in the 1930s known popularly as the Brownlow Commission, which recommended that the merit system be extended throughout the federal 
government. By the end of the Roosevelt's administration in 1945, 90 percent of federal employees were covered under the merit system.

Nevertheless, it was the court system that finally, issued the death knell for widespread patronage systems at all levels of government. They did so in a series of decisions that the Supreme Court issued between 1976 and 1990. These decisions greatly limited patronage appointments in government. Those cases were:

- Elrod v. Burns (1976) - in this case the U.S. Supreme Court held that Elrod, the elected Sheriff of Cook County, Illinois, could not dismiss county employees because they were members of an opposing political party.

- Branti v. Finkl (1980) - in this case the U.S. Supreme Court held that only policy makers who had responsibilities of a partisan nature could be fired because of their party affiliation.

- Rutan v. Republican Party of Illinois (1990) - in this case the U.S. Supreme Court overruled the Republican Governor of Illinois's decision to exempt only Republican Party appointees from a governor-imposed hiring freeze.

Thus, the patronage system in the United States was greatly shrunken for several reasons. First, influential citizens organized themselves beginning in the late $19^{\text {th }}$ Century to put pressure on legislative bodies to enact civil service reform legislation. They also inspired the councilmanager form of government, which sprung up in thousands of cities and towns in the United States. Second, political leaders, particularly President Franklin Roosevelt in the latter part of his administration and the U.S. Congress exercised leadership in minimizing patronage. Third, the Supreme Court in their interpretation of the U.S. Constitution ruled patronage systems to be unconstitutional.

\section{ADVANTAGES OF A MERIT-BASED HIRING SYSTEM}

Aside from the pressure exerted by the European Commission to introduce a merit-based hiring system in North Macedonia, there are multiple reasons why the North Macedonian government should do so, including

- Creation of good governance;

- Improvement of morale among government employees; 
- Development of public confidence;

- Reduction of the influence of ethnic politics; and

- Reinforcement of the rule of law.

Creation of good governance: The work of government is becoming increasingly complex and it is becoming more important that the government is staffed by competent employees who can adequately perform their jobs. Indeed, at the core of the merit-based hiring system is a simple philosophy - matching unfilled positions with competent job candidates. A nation's taxpayers deserve a government that is properly staffed with people who know how to do their jobs. In order to do their jobs, those employees should have the requisite knowledge, skills and abilities. The government should not be staffed by amateurs and that is typically what happens when there is a patronage system in place.

Improvement of morale among government employees: Employees like to be treated fairly. Fairness is at the heart of any good merit-based hiring system. A system in which loyalty to a political party is valued over competence is bound to create disharmony within an organization's ranks. Current employees who are not hired because they are less politically influential than their more politically influential colleagues are likely to become discouraged and their work product will inevitably suffer.

Development of public confidence: It is imperative that governments serve the people - not merely one segment of the people. Public confidence is enhanced when neutrally competent government workers equitably provide goods and services to the citizens they are designated to serve. The cynicism that many citizens direct toward their government in North Macedonia is undoubtedly related in many cases to a feeling that citizens currently are not being served well by government workers perhaps in some instances because the government worker is a member of a different ethnic group or political party than the person he or she are supposed to serve. The authors believe individuals selected through a merit-based hiring system are more likely to serve the country's citizens fairly without discrimination, because they would not owe their job to a particular political party, but instead would be selected through a fair process that rewards competence rather than political loyalty.

Reduction of the influence of ethnic politics: In multiethnic societies achieving equitable representation in public administration or deficit of representation is always on the political agenda leaving great deal of political leverage to political parties whose ethnic identity is dominant over political ideology. Effective representation in public administration systems is 
critical to a participative bureaucracy in that it involves all groups in decision making process and government. A way forward to minimize the effects of ethnic politics in public administration system is thorough policies that promote effective representation of all groups that build inclusive, participative public administration systems.

Reinforcement of the rule of law: "The rule of law is fundamental to all liberal constitutional regimes whose political orders recognize the equal natural rights of all and whose purpose is to protect those natural rights in addition to the general welfare" (Anthony, 2009, p. 6). And it is government, which must model a commitment to the rule of law, if it is to take hold and be sustained within a society. One cannot expect a country's private sector to adhere to the rule of law, if government itself does not practice it. Establishing and maintaining a merit-based hiring system in government is a very important means which helps sustain the rule of law.

\section{WHAT DOES A MERIT-BASED HIRING SYSTEM LOOK LIKE?}

How can the previously stated goals be achieved? We believe that the process by the American federal government is an excellent example. In that model, the human resources officer is the subject matter expert with respect to the hiring process and ensures that all applicable rules are complied with. In the case of the U.S. federal government, to ensure accountability, the work of the human resource officer may be subject to review by the central personnel office, namely the U.S. Office of Personnel Management (OPM). Furthermore, applicants who feel that a particular hiring process was unfair may appeal a hiring decision to another agency - the Merit System Protection Board. Throughout the process, the human resource officer plays essentially two roles, one of "guardian of the rules" and the other of providing service to the hiring manager.

In this model, there are five principal steps in the hiring process:

1. The hiring officer in coordination with the human resources officer reviews the job that needs to be filled.

2. The hiring officer in coordination with the human resources officer recruits and announces the job.

3. The human resources officer accepts and reviews job applications.

4. The human resource officer ranks the candidates and presents the three top candidates to the hiring officer. 
5. The hiring officer interviews the candidates and makes the selection

Step 1: At this stage of the process, the human resource officer and the hiring officer meet and review the amount of flexibility they can exercise in the hiring process. They ask budget questions, namely:

- Does the hiring officer have sufficient money in his or her budget to hire a new employee?

- Furthermore, since most managers in the U.S. federal government are also constrained by the number of full-time equivalent (FTE) people that they employ, they will also discuss whether the hiring manager's number of employees still falls within his or her FTE allocation?

They ask substantive questions related to the job like:

- What types of knowledge and/or experience are needed for the position?

- What kind of educational degrees and/or certificates are required, if any?

- To what extent can education substitute for experience or vice versa?

- Should the job have "promotion potential," namely can the person occupying the position be promoted to a higher rank non-competitively?

- Should the position be temporary or permanent?

There are also process questions, specifically:

- Can the hiring officer hire a candidate non-competitively or through the competitive process? (Until recently in the federal government, new college graduates could be hired non-competitively if their grade point average exceeded 3.5 on a 4.0 scale during their undergraduate career.)

- Should the hiring officer interview candidates or should that person employ an assessment center? (An assessment center is a series of behavioral tests in which job candidates in a simulated environment undergo behavioral tests related to functions that they would perform as employees for the position for which they are applying for. For example, a person competing for a managerial position might be asked to place in priority order a number of tasks common to that position.) 
- Should the position be filled by means of an examination?

There is also the question at what grade the position should be filled. The U.S. Office of Personnel Management OPM) has developed what they call the "Factor Evaluation System," which uses nine criteria to determine a position's grade and subsequent salary. Those criteria are the following:

- Knowledge required - an analysis of what kind and level of knowledge is needed;

- Supervisory controls - the level of responsibility that the employee exercises in carrying out the job;

- Guidelines - the amount of discretion the employee is supposed to exercise;

- Complexity - an analysis of how difficult the tasks are associated with the job;

- Scope and effect - the impact the job has on the organization and its overall mission;

- Personal contacts - an analysis of how many people the job incumbent would contact, and in what situations;

- Purpose of contacts - an analysis to what extent information is exchanged, problems solved, services rendered and/or negotiations undertaken;

- Physical demands - the intensity of the physical work; and

- Work environment - how uncomfortable is the worker's surroundings (OPM, 1991).

These criteria are each given a different weight and are listed in descending order. In the OPM scheme, the criteria of knowledge required accounts for more than 40 percent of the weighting, whereas work environment accounts for less than one percent.

Step 2: During this step in the process the hiring officer in coordination with the human resources officer develops a recruitment strategy, which eventually results in a vacancy announcement. As part of that strategy, they ask the following questions:

- Should both external and internal candidates be considered for the position?

- Should only candidates who live within a certain distance from the office be considered so as to eliminate the need for the hiring agency to pay moving costs? 
- How long should the position be open (In most cases, the shortest time frame is two weeks.)

- Should the manager take active steps to try to encourage applicants to apply for the position?

- And if so, what active steps should the hiring manager undertake that comply with personnel management policies?

Step 3: Once the job announcement is closed, the human resources officer reviews the available applicants. During the first part of this process, the human resources officer excludes those applicants that fall below the minimum qualifications for the job.

Furthermore, in the United States federal government, people who have served in the military receive a preferential advantage. An additional advantage is given to those applicants who served in the military and during their time of service incurred a disability. Thus, the human resources officer makes note of these advantages and the advantages are translated into points - in this case five points for a veteran and ten points for a disabled veteran. (The maximum point total is 100.)

Step 4: At this stage in the process, the human resources officer analyzes all of the qualified applicants. The human resources officer examines each candidate against a variety of criteria. For example, the human resources officer might ask the following questions:

What degrees and/or certificates does an applicant hold?

- How relevant is an applicant's experience related to the job in question?

- How much responsibility did an applicant exercise in previous positions?

- Is the job application well-written and concise?

- Does the applicant make a convincing case that he or she can do the job?

After carefully examining all the qualified applications, the human resources officer determines who are the top three candidates.

Step 5: At this stage, the hiring officer is usually required to interview all three candidates. Before completing the process, the hiring officer writes a justification for why he or she chose the finalist. 


\section{CONCLUSION}

A merit-based hiring system is an essential element of a professionalized civil service and a professionalized civil service is a necessity in a liberal democratic society. A merit-based hiring system will help ensure a more responsive, equitable and competent government. Governments, which employ a merit-based hiring systemadmittedly have their flaws, but they are much preferable to patronage systems in that they exhibit more fairness and result in the hiring of more competent employees.

The transformation to a merit-based hiring system in North Macedonia will not be an easy process. As the authors, note, it took about 150 years for the governments in the United States to reject their systems of patronage. It is especially hard to overturn an entrenched patronage system, which is based on loyalty to one's ethnic group's political party. Given the longstanding ethnic cleavages in North Macedonia, perhaps it was inevitable that a patronage system developed here. Similar ethnic cleavages also occurred in the United States and they occur today with Donald Trump's appeal to white nationalism. Perhaps a merit-based hiring system will most likely be achieved when more North Macedonians begin to put their country first and their ethnicity second.

\section{REFERENCES}

- Berat, D. (2017). Ethnic parties: Definition and classification. SEEU review. 2(2), 108-120.

- Branti v. Finkl 445 U.S. 507 (1980).

- Crowther, W. (2017). Ethnic condominium and illiberalism in Macedonia. East European politics and society. 31(4), 739-761.

- Elrod v. Burns 427 U.S. 347 (1976).

- European Commission (2016). Commission staff working document: The Former Yugoslav Republic of Macedonia 2016 Report.

- Mojanoski, C. (1996). Social and Political Profile of the Political Parties in Macedonia. Skopje: Liber.

- Petkovski, L. (2015). Authoritarian populism and hegemony: Constructing 'the people' in Macedonia's illiberal discourse. Contemporary Southeastern Europe.3(2), 44-66.

- Rutan v. Republican Party of Illinois 497 U.S. 62 (1990).

- Suleiman, E. (2003) Dismantling democratic states. Princeton, New Jersey, USA, Princeton University Press.

- Skaric, S. (2004) Political Parties and the Party System in Macedonia. In Dimitri Tsatsos et al. (Eds.), Political Parties in the $21^{\text {st }}$ century (pp.309-335). Athens: Ant. N. Sakkoulas.

- Taleski, D. (2008) Minorities and Political Parties in Macedonia. In Friedrich Ebert Stiftung (Ed.), Political Parties and Minority Participation (pp.127-151). Skopje: FES.

- U.S. Office of Personnel Management (1991). The Classifier's Handbook. 